by Ian M. Tyler, Roger M. Hocking and Peter W. Haines

\title{
Geological evolution of the Kimberley region of Western Australia
}

Geological Survey of Western Australia, 100 Plain Street, East Perth WA 6004, Australia. E-mail: ian.tyler@dmp.wa.gov.au; roger.hocking@dmp.wa.gov.au; peter.haines@dmp.wa.gov.au

The history of the Kimberley region in the far north of Western Australia began in the Paleoproterozoic with rifting along the North Australian Craton margin at 1910-1880 Ma, followed by plate collision as part of a series of 1870-1790 Ma events that formed the Diamantina Craton within the supercontinent Nuna. Collision involved the accretion of an intra-oceanic arc to a continent that included the Kimberley Craton before final collision and suturing with the North Australian Craton. The c. 1835 Ma Speewah Basin formed as a retro-arc foreland basin to the $W$. The post-orogenic, c. $1800 \mathrm{Ma}$ shallow-marine to fluvial Kimberley Basin and its equivalents had a provenance to the $N$ and extended across both the Lamboo and Hooper provinces. Subsequent late Paleoproterozoic and Mesoproterozoic basins formed broadly similar depositional settings during break-up and reassembly into the supercontinent Rodinia. The intracratonic Yampi Orogeny generated large-scale folding and thrusting and sinistral strike-slip faulting between 1400-1000 Ma.

The Neoproterozoic Centralian Superbasin formed as a broad intracratonic sag basin throughout central Australia between c. 830 Ma and the earliest Cambrian, including a series of basins across the Kimberley. Glacigene rocks are present with the most widespread being equivalent to the c. 610 Ma Elatina ("Marinoan") glaciation. Folding, thrusting and strike-slip faulting during the c. 560 Ma King Leopold Orogeny caused a widespread unconformity at the base of the Ord and Bonaparte basins marked by the c. 508 Ma Kalkarindji Continental Flood Basalt Province. In the Early Ordovician, thermal subsidence initiated the Canning Basin. Paleozoic sedimentary rocks, including Devonian reef complexes, were deposited on the Lennard Shelf and in the Fitzroy Trough. In the Halls Creek Orogen, Devonian sedimentary rocks were deposited in subbasins of the Ord Basin during the c. 450-300 Ma Alice Springs Orogeny. A widespread glacigene succession followed in the Canning Basin, but by the early Triassic deposition was restricted and the remainder of the Mesozoic succession forms a veneer over much of the basin.

\section{Introduction}

The geological history of the Kimberley region in the far $\mathrm{N}$ of Western Australia (Figures 1 and 2) is complex and spans almost 2 billion years of earth history. A period of Paleoproterozoic plate collision during the assembly of the supercontinent Nuna produced crystalline basement rocks forming the Hooper and Lamboo provinces. Collision and suturing was followed through the rest of the Proterozoic and the Phanerozoic by repeated phases of sedimentary basin formation, orogenic deformation, and associated fault reactivation at upper crustal levels, first within Nuna, then Rodinia and finally Gondwana. Deposition essentially ceased in the Late Paleozoic, and in the Neogene the region began to bow downwards as Australia met the Indian plate.

\section{Paleoproterozoic plate collision (1910- 1805 Ma)}

The oldest exposed rocks in the Kimberley region are igneous and low- to high-grade meta-igneous and metasedimentary rocks that occur within the 1910-1790 Ma Lamboo and Hooper provinces (Figures 1 and 2). The Halls Creek Orogen (Figure 2) is a suture formed by plate collision between the southeastern margin of a continent including the Kimberley Craton (which underlies the Speewah and Kimberley basins) and the NW margin of the North Australian Craton, and the Halls Creek Orogeny was one of a series of linked collisional events that formed the Diamantina Craton as part of the supercontinent Nuna (Cawood and Korsch, 2008). Collision was complex, involving the accretion of the Tickalara arc to the Kimberley Craton during the 1870 -1850 Ma Hooper Orogeny (Figures 3 and 4), before suturing during the 1835-1805 Ma Halls Creek Orogeny (Blake et al., 2000; Griffin et al., 2000; Sheppard et al., 1999, 2001; Tyler, 2005).

\section{The Lamboo and Hooper Provinces}

The Lamboo Province in the Halls Creek Orogen can be divided into three zones; the Western zone, the Central zone and the Eastern zone (Figure 2). The Hooper Province in the west Kimberley is an 


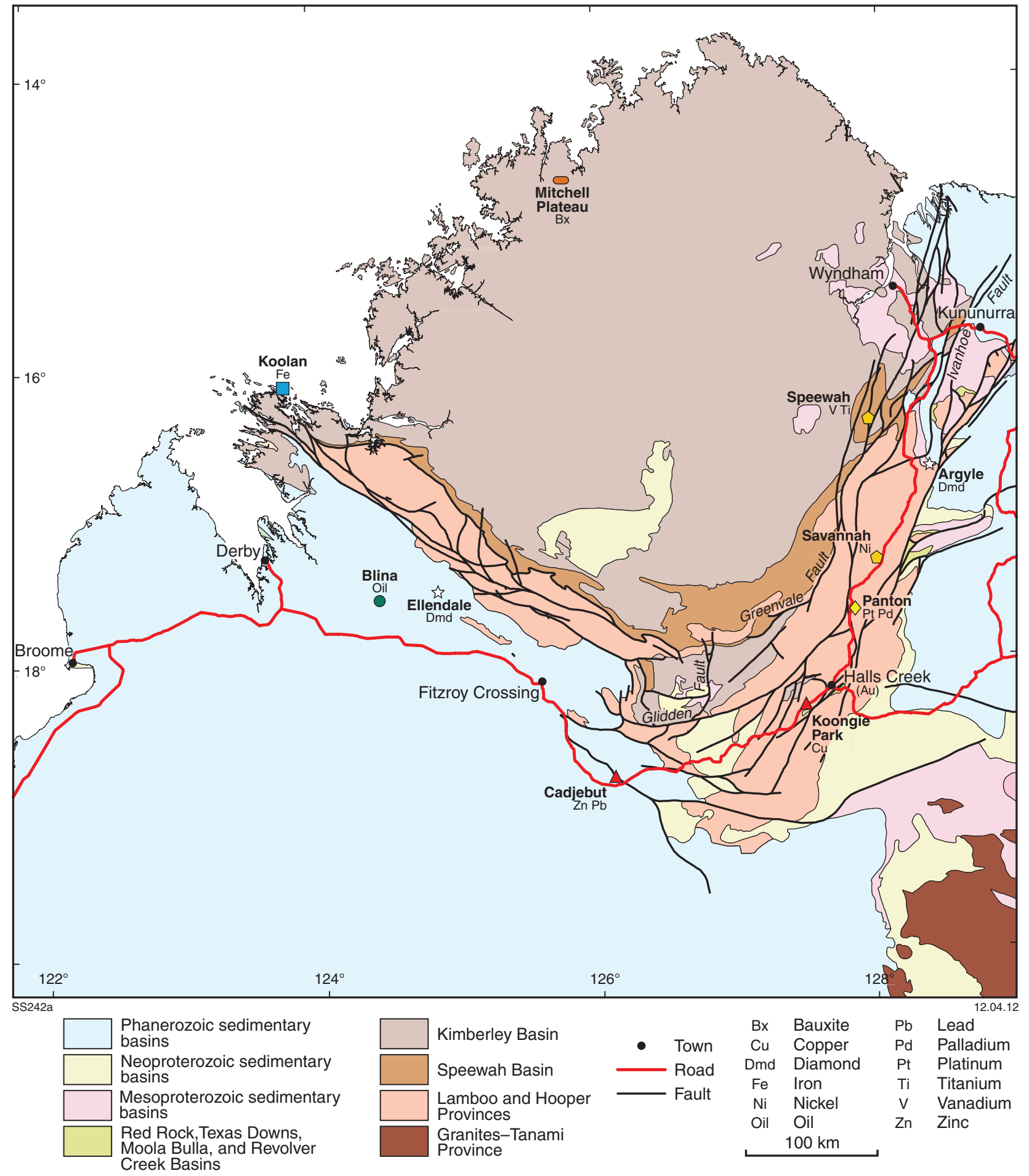

Figure 1 Tectonic units in the Kimberley region (after Tyler and Hocking, 2001).

extension of the Western zone (Tyler et al., 1995; Griffin et al., 2000). Stratigraphic units cannot be correlated across the zone boundaries, which is consistent with the zones forming Paleoproterozoic tectonostratigraphic terranes (Tyler et al., 1995).

\section{Hooper Province and the Western zone of the Lamboo Province}

The oldest rocks in the Hooper Province and the Western zone of the Lamboo Province (Figure 2) are low- to high-grade turbiditic metasedimentary rocks of the c. 1870 Ma Marboo Formation representing rifting marginal to the Kimberley Craton following accretion of earlier Paleoproterozoic exotic terranes (Figure 3; Griffin et al., 1993, 2000; Tyler et al., 1999). Partial melting of intermediate - felsic, calc-alkaline rock within these source terranes formed the felsic volcanic rocks of the unconformably overlying the Whitewater Volcanics, which were deformed and metamorphosed, and extensively intruded by potassic, I-type granitic and sub-volcanic rocks, as well as gabbroic rocks, and layered mafic-ultramafic intrusions of the Paperbark Supersuite during the 1865-1850 Ma 


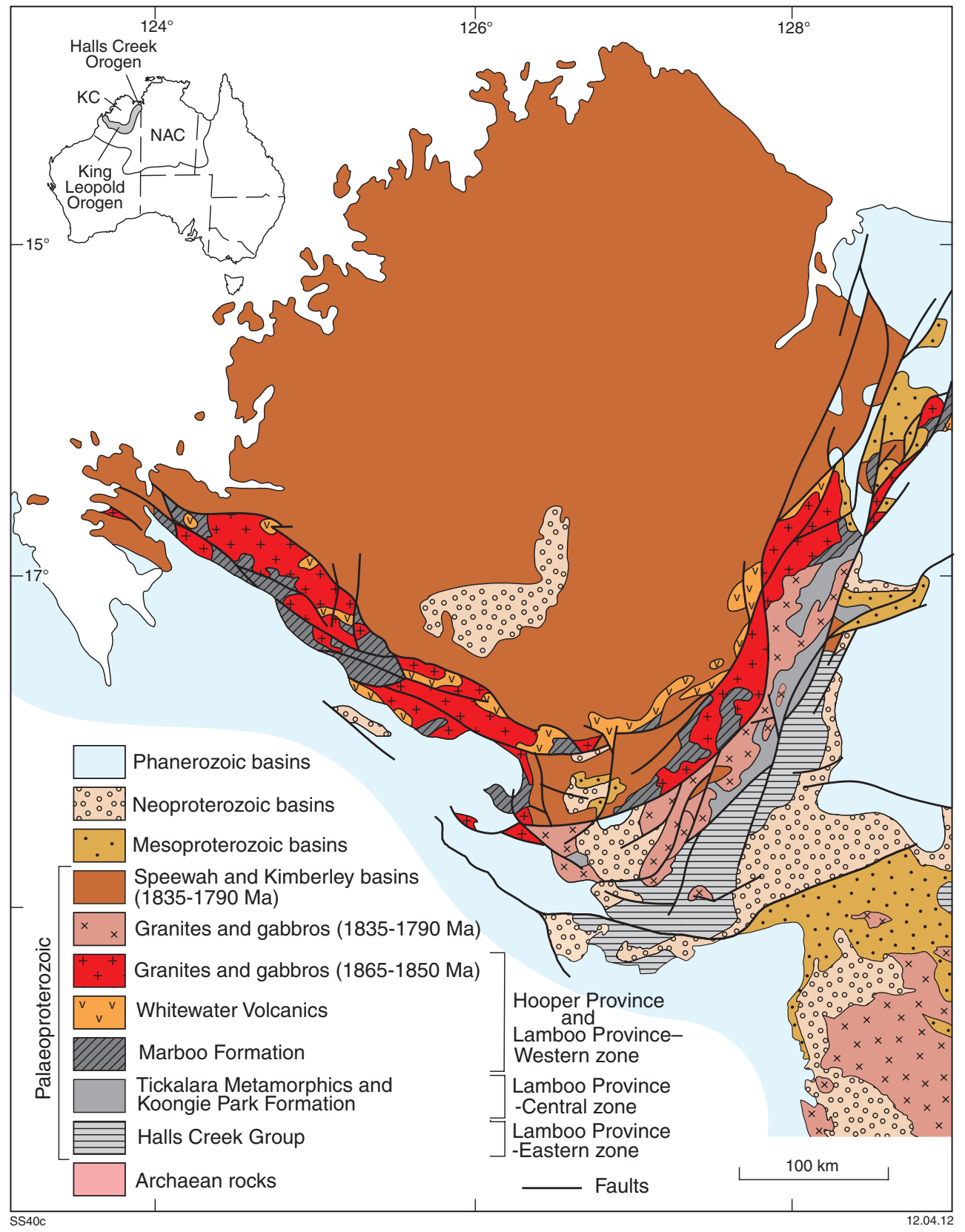

Figure 2 Paleoproterozoic geology of the Kimberley region. The inset shows the locations of the North Australian Craton (NAC) and the Kimberley Craton (KC) (from Griffin et al., 2000).

were deposited at $1845-1840 \mathrm{Ma}$ during rifting of the arc (Page et al., 1994; Tyler et al., 2005). Layered mafic-ultramafic bodies were intruded into the Central zone at c. 1856, c. 1845 and $1830 \mathrm{Ma}$ (Page and Hoatson, 2000). Large volumes of granite and gabbro of the Sally Downs Supersuite intruded the Central zone during the Halls Creek Orogeny at 1835-1805 Ma (Tyler and Page, 1996; Page et al., 2001).

\section{Eastern zone of the Lamboo Province}

The Eastern zone (Figure 2) c. 1910 Ma mafic and felsic volcanic rocks of the Ding Dong Downs Volcanics and associated granitic rocks are unconformably overlain by low-grade metasedimentary and metavolcanic rocks of the Halls Creek Group (Tyler et al., 1998). At the base of the Halls Creek Group the quartz sandstone of the Saunders Creek Formation contains exclusively Archean detrital zircon populations (3600 Ma - 2512 Ma; Blake et al., 1999; Tyler et al., 2005). Overlying mafic volcanic rocks of the Biscay Formation in the lower part of the Halls Creek Group were erupted at c. 1880 Ma on a passive continental margin along the western edge of the North Australian Craton (Figure 3; Sheppard et al., 1999).

The overlying turbiditic metasedimentary rocks of the Olympio Formation record a transition from a passive to an active margin and can be divided into upper and lower units separated by alkaline volcanism at $\mathrm{c}$. $1857 \mathrm{Ma}$ and c. $1848 \mathrm{Ma}$ (Blake et al., 1999, 2000). The turbiditic rocks form

Hooper Orogeny (Griffin et al., 2000; Page and Hoatson, 2000; Page et al., 2001).

\section{Central zone of the Lamboo Province}

The Central zone (Figure 2) is dominated by medium - highgrade turbiditic metasedimentary and mafic volcanic and volcaniclastic rocks of the Tickalara Metamorphics, interpreted as an oceanic island arc developed at c. $1865 \mathrm{Ma}$ (Figure 3; Sheppard et al., 1999; Griffin et al., 2000). These were intruded by tonalitic sheets, and deformed and metamorphosed between c. 1865-1856 Ma and at 1850-1845 Ma (Bodorkos et al., 1999, 2000a; Blake et al., 2000; Page et al., 2001). In the southern part of the Central zone, sedimentary rocks and mafic and felsic volcanic rocks of the Koongie Park Formation part of two submarine-fan systems in an evolving foreland basin, with sediment derived from predominantly continental, granitic sources to the NW, the oldest at c. $1873 \mathrm{Ma}$ and the youngest at c. 1847 Ma (Hancock, 1991; Tyler, 2005; Tyler et al., 2005). The Halls Creek Group was deformed and metamorphosed during the 18351805 Ma Halls Creek Orogeny, and were stitched to the central zone by the $1820-1810$ Ma granites of the Sally Downs Supersuite.

\section{Hooper Orogeny}

The Hooper Orogeny was recognised first in the Hooper Province (Tyler and Griffin, 1993; Griffin et al., 1993), and took place between c. $1870 \mathrm{Ma}$ and c. $1850 \mathrm{Ma}$. Rocks of the Marboo Formation are affected by two early phases of deformation. The first was between 


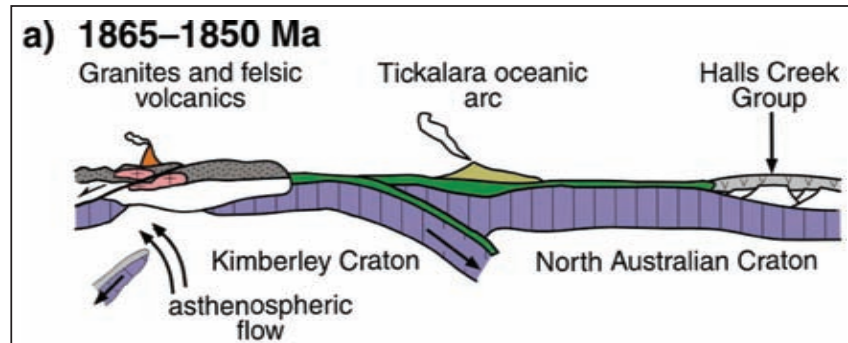

b) $1850-1845 \mathrm{Ma}$

accretion of Tickalara arc

Halls Creek Group

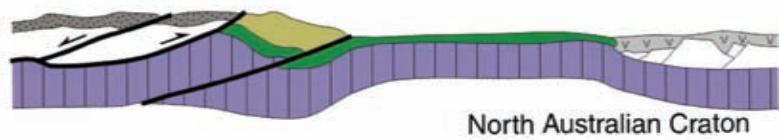

SS69a

17.11 .11

Figure 3 Plate tectonic setting of the Kimberley during the Hooper Orogeny (from Griffin et al., 2000).

c. $1870 \mathrm{Ma}$, the age of the youngest detrital zircons in the Marboo Formation, and c. $1865 \mathrm{Ma}$, the age of the intrusion of the oldest Paperbark Supersuite intrusions (Tyler et al., 1995, 1999; Griffin et al., 2000). The second deformation and accompanying metamorphism was coeval with the emplacement of the Paperbark Supersuite between 1865 and $1850 \mathrm{Ma}$, and deformed the c. $1855 \mathrm{Ma}$ Whitewater Volcanics (Griffin et al., 1993; Tyler et al., 1995, 1999).

The first deformation in the Central zone post-dates the c. 1863 Ma age of the Rose Bore Granite, while a minimum age is provided by the c. 1850 Ma granitic rocks of the Dougalls Suite, which postdates the first deformation but pre-dates the second (Blake et al., 2000; Tyler, 2005). These age constraints are similar to those for the second deformation in the Western zone, suggesting both deformations are linked to the accretion of the Tickalara arc (Thorne et al., 1999; Blake et al., 2000).

\section{Halls Creek Orogeny}

Deformation and metamorphism during the Halls Creek Orogeny affected the entire Lamboo Province (Tyler et al., 1995; Blake et al., 2000). In the Central zone the first deformation occurred synchronously with the intrusion of the c. 1835 Ma Mabel Downs Tonalite (Bodorkos et al., 2000b; Page et al., 2001). The second deformation refolds earlier structures and is cut by c. 1810 Ma granite intrusions (Page et al., 2001).

The Sally Downs Supersuite was intruded between c. $1835 \mathrm{Ma}$ and c. $1805 \mathrm{Ma}$ and its granitic rocks range from syn-collisional, crustally derived adakites through to post-collisional, potassic types (Sheppard et al., 2001).

\section{Speewah Basin}

During the Halls Creek Orogeny, siliciclastic sedimentary rocks of the $1.5 \mathrm{~km}$ thick Speewah Group were being deposited in the $\mathrm{c}$. 1835 Ma Speewah Basin, unconformably overlying the northern and western margins of the Western zone of the Hooper and Lamboo provinces (Figure 1). The Speewah Group thins dramatically to the W, and is overlapped by the Kimberley Group in the SE. The presence of c. 1834 Ma felsic volcanic rocks within the Valentine Siltstone, near the base of the succession, suggest the basin developed at the same time as the intrusion of granitic and gabbroic rocks into Lamboo Province at c. $1835 \mathrm{Ma}$ (Tyler et al., 1995; Blake et al., 2000; Tyler, 2000; Sheppard et al., 2012). Paleocurrent data indicate a provenance from the NE, from the core of the uplifted Lamboo Province with deposition taking place in a retro-arc foreland basin behind the active eastern margin of the Kimberley Craton (Gellatly et al., 1970; Sheppard et al., 2012).

\section{Post-collisional Kimberley Basin and its equivalents (c. $1800 \mathrm{Ma}$ )}

The Kimberley Group comprises a $3 \mathrm{~km}$-thick succession of siliciclastic sedimentary rocks and mafic volcanic rocks deposited in the Kimberley Basin (Figure 1), which disconformably overlies the Speewah Group, but pre-date the c. 1797 Ma Hart Dolerite (Sheppard et al., 2012). Paleocurrent data indicate a provenance from the N, beyond the present Australian plate, with deposition taking place in a broad, semi-enclosed, shallow marine basin (Gellatly et al., 1970).

The Moola Bulla, Red Rock, Texas Downs and Revolver Creek basins are probable equivalents to the Kimberley Group that outcrop across the Halls Creek Orogen (Figure 1; Thorne et al., 1999; Blake et al., 1999).

\section{Hart Dolerite and Wotjulum Porphyry}

The Hart Dolerite is a large igneous province that consists of a network of connected sills and dykes of massive dolerite and less extensive granophyres, with a combined thickness of up to $3 \mathrm{~km}$, which are mainly intruded into the Speewah Group and lower Kimberley Group around their deformed SE and SW margins (Sheppard et al., 2012). The intrusions underlie an area of c. 160,000 $\mathrm{km}^{2}$ and have an estimated volume of $250,000 \mathrm{~km}^{3}$ (Griffin et al., 1993). The granophyres have been dated at c. 1797 Ma. The Hart Dolerite records part of a post-collisional magmatic event related to plate re-organisation, and was sourced from subduction-modified mantle beneath the Kimberley Craton (Sheppard et al., 2012).

The c. 1740 Ma Wotjulum Porphyry intrudes as a sill into the upper Kimberley Group in the Yampi Peninsula (Tyler and Griffin, 1993; Sheppard et al., 2012).

\section{Intracratonic Proterozoic Basins and orogenies (1800-508 Ma)}

Collision and suturing was followed by two broad cycles of sedimentary basin formation, followed by intracratonic orogenic deformation and associated fault reactivation. The first spanned the late Paleoproterozoic and Mesoproterozoic as Nuna broke up and Proterozoic Australia was reassembled into Rodinia; the second reflects Neoproterozoic breakup of Rodinia followed by the assembly of Gondwana (Tyler, 2005).

\section{Paleoproterozoic - Mesoproterozoic basins}

The ages of the Bastion, Crowhurst and Osmond basins are uncertain but they all overlie the Kimberley Group or its equivalents 


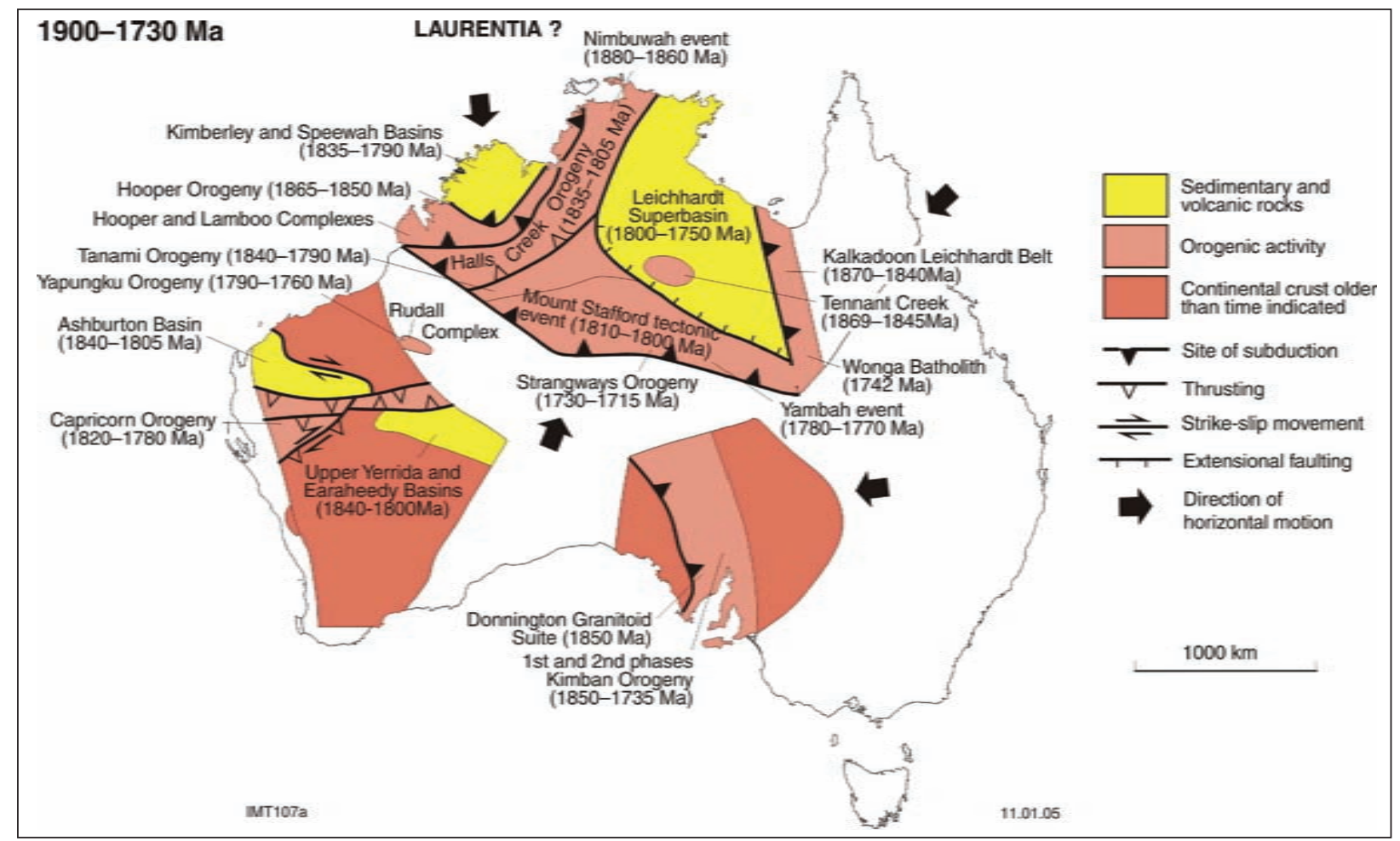

Figure 4 Model for the assembly of the Diamantina Craton, as proposed by Tyler (2005).

(Figure 1) and are regarded as younger than c. $1797 \mathrm{Ma}$. Based on limited isotopic dating and correlation with other units, Thorne et al. (1999) suggested deposition took place in the late Paleoproterozoic - early Mesoproterozoic. Siliciclastic sedimentary rocks of the Bastion Group, deposited in a similar environment to the Kimberley Group, unconformably overlie the Kimberley Basin in the northeastern Halls Creek Orogen, and are overlain by the c. 508 Ma Cambrian Antrim Plateau Volcanics (Plumb and Gemuts, 1976; Thorne et al., 1999). The Crowhurst Group, which includes stromatolitic dolomite, occupies a similar setting overlying the Kimberley Basin at the southern end of the Halls Creek Orogen, and the siliciclastic Mount Parker Formation and the overlying stromatolitic Bungle Bungle Dolomite were deposited in the Osmond Basin on the eastern side of the Halls Creek Orogen (Tyler, 2000).

The siliciclastic rocks of the $4.4 \mathrm{~km}$-thick Carr Boyd Group unconformably overlie both crystalline rocks of the Lamboo Province and equivalents of the Kimberley Group (Thorne et al., 1999) in the northeastern Halls Creek Orogen (Figure 1). They are in turn unconformably overlain by Neoproterozoic glacial deposits of the Wolfe Creek Basin. Deposition of the Carr Boyd Group probably took place in a deltaic to shallow-marine setting at c. $1200 \mathrm{Ma}$, the age of intrusion of the Argyle lamproite diatreme into wet sediments (Thorne and Tyler, 1996; Jaques et al., 1986; Pidgeon et al., 1989).

The Glidden Group and Wade Creek Sandstone have been correlated with the Carr Boyd Group (Tyler, 2000; Blake et al., 2000).

\section{Yampi Orogeny}

The Mesoproterozoic Yampi Orogeny took place between c. 1400$1000 \mathrm{Ma}$, based on K-Ar dating (Shaw et al., 1992) and Ar-Ar dating (Bodorkos and Reddy, 2004) and produced large-scale, NE-facing folds and thrusts in the Speewah and Kimberley Basin successions on the Yampi Peninsula (Yampi Fold Belt) (Tyler and Griffin, 1990,
1993; Griffin et al., 1993). Thrusts can be followed into NW-trending, SW-dipping ductile shear zones in the Hooper Province. Deformation was accompanied by a low- to medium-grade metamorphic event with the development of large porphyroblasts of garnet, andalusite and staurolite (Griffin et al., 1993; Bell and Mares, 1999). Large-scale strike-slip faulting took place in the Halls Creek Orogen during the Yampi Orogeny, and established a pattern of N-NE-trending synthetic sinistral faults, and E-NE-trending antithetic dextral faults (White and Muir, 1989; Tyler et al., 1995; Thorne and Tyler, 1996), consistent with the thrusting in the Yampi Fold Belt.

\section{Neoproterozoic Basins}

The Paleoproterozoic and Mesoproterozoic rocks are overlain unconformably by Neoproterozoic sedimentary rocks of the Wolfe Creek Basin, the upper Victoria River Basin, and the Louisa Basin in the Halls Creek Orogen, and by the Mount House Group and Oscar Range Group in the King Leopold Orogen (Figure 1). These linked basins are part of the Centralian Superbasin (Grey and Blake, 1999; Tyler, 2005), interpreted by Walter et al. (1995) as a broad intracratonic sag basin that extended throughout much of central Australia between c. $830 \mathrm{Ma}$ and the earliest Cambrian. Stromatolitic dolomite in the Ruby Plains group can be correlated with Supersequence 1 (Grey and Blake, 1999). Several glacigene intervals are present, with the most widespread being equivalent to the c. 610 Ma Elatina ("Marinoan") glaciation of Supersequence 3 (Grey and Corkeron, 1998). Glacial straie are preserved across the Kimberley region.

\section{King Leopold Orogeny}

The c. 560 Ma King Leopold Orogeny produced extensive, well exposed, W-NW- trending fold and thrust structures in the King Leopold Ranges (Precipice Fold Belt), along the SW margin of the 
Kimberley Basin, together with reactivation of shear zones in the Hooper Province (Tyler and Griffin, 1990, 1993; Shaw et al., 1992; Griffin et al., 1993). South-directed thrusting is linked to sinistral strike-slip faulting in the Halls Creek Orogen and deformation affected Neoproterozoic glacigene rocks. Deformation occurred about the same time as the Paterson Orogeny at the NE edge of the Pilbara Craton, and the Petermann Orogeny in central Australia (Tyler, 2005).

\section{Phanerozoic Basins}

A thick Paleozoic and Mesozoic succession is present in the Canning Basin, in the SW Kimberley, and in the Ord and Southern Bonaparte basins, in the eastern and northern Halls Creek Orogen (Figure 1). The King Leopold Orogeny gave rise to a widespread unconformity prior to extrusion of c. $508 \mathrm{Ma}$ basaltic rocks of the Antrim Plateau Volcanics and deposition of middle - upper Cambrian sedimentary rocks in the Ord and Southern Bonaparte basins (Mory and Beere, 1988). The volcanic rocks are part of the extensive Kalkarindji Continental Flood Basalt Province that originally extended across $300,000 \mathrm{~km}^{2}$ of northern Australia (Hanley and Wingate, 2000; Glass and Phillips, 2006). In the Halls Creek Orogen, sinistral strike-slip faulting and associated folding and thrusting related to the c. $450 \mathrm{Ma}-300 \mathrm{Ma}$ Alice Springs Orogeny in central Australia (Mory and Beere, 1988; Thorne and Tyler, 1996) resulted in the development of a series of Devonian sub-basins (Ord Basin) adjoining basinbounding faults.

Cambrian rocks are absent SW of the Halls Creek Orogen. There, Ordovician and younger rocks of the Canning Basin (Hocking et al., 2008) unconformably overlie or are faulted against Proterozoic rocks (Haines, 2009; Griffin et al., 1993). Ordovician rocks are exposed in a thin sliver along the northern margin of the basin on the Lennard Shelf, beneath the exhumed Devonian reef complexes and associated conglomerates (Playford et al., 2009, and references therein), reflecting a much thicker Ordovician and Silurian succession in the subsurface of the central and southern Canning Basin.

\section{Devonian reef complexes}

Middle and Upper Devonian (Givetian, Frasnian, and Famennian) reef complexes form a belt of rugged limestone ranges, some $350 \mathrm{~km}$ long and as much as $50 \mathrm{~km}$ wide, on the Lennard Shelf, along the northern margin of the Canning Basin (Playford et al., 2009). The

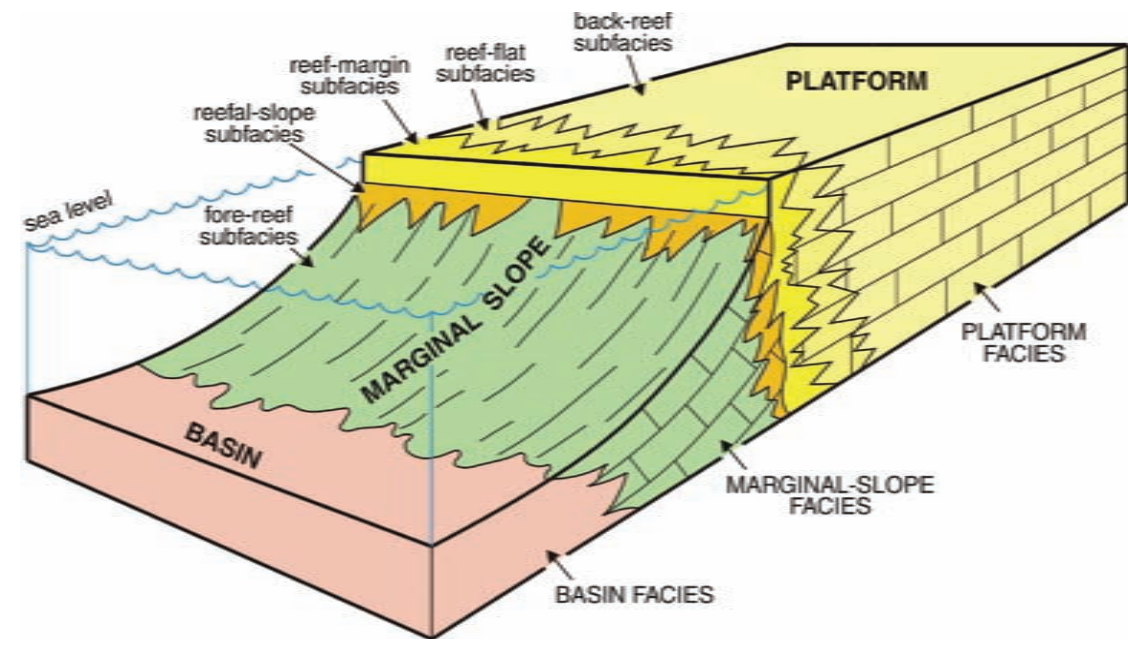

Figure 5 Reef complexes and facies subdivisions (from Playford et al., 2009, Figure 16). reef complexes are spectacularly exposed as a series of fringing reefs, atolls, and banks, which grew along the mountainous mainland shore of the Kimberley, and around rugged islands. Three main facies are recognised in the reef complexes: platform, marginal slope, and basin (Figures 5-7). The reefs are almost undeformed, with only local tilting due to normal fault movement.

Conglomerates interfinger with and cut through the reef complexes at prominent drainage notches related to the scarps of active faults in adjoining Proterozoic basement (Figure 6), and have been intersected (but not studied in detail) by some petroleum exploration drillholes basinward of the outcrop belt. In outcrop, conglomerate bodies interfinger with cyclic platform carbonates. They span many metrescale cycles, indicating deposition of each body extended over a few million years rather than tens or hundreds of thousands of years, and tectonic rather than eustatic control (Hocking and Playford, 2002). The Famennian phase of conglomerate deposition is attributed to a major episode of the Alice Springs Orogeny of central Australia.

The outcropping complexes preserve continued highstand deposits, with corresponding lowstand deposits preserved basinwards (to the $S$ ) in the subsurface. In outcrop, reefal development shows a broad transgressive-regressive cycle upon which several events are superimposed. In the Givetian and Frasnian, reefs showed an overall backstepping pattern, in which vertical reef growth was punctuated by abrupt backsteps, related to a sharp but small sea level fall followed by rapid transgression and drowning of the reef platform. These events appear to be irregular, and thus possibly of tectonic rather than eustatic origin. In the latest Frasnian, at the peak of transgression and just prior to the Frasnian / Famennian global extinction event, there was rapid progradation and horizontal reef growth. Regression in the Famennian led to the reefs prograding in shallower water conditions, although subsidence still outstripped the rate of regression. Many Famennian reef builders migrated upwards from deeper water areas to take the place of newly extinct Frasnian builders such as stromatoporoids.

\section{Carboniferous-Permian glaciations}

In the Late Carboniferous and Early Permian, continental-scale glaciation by $\mathrm{N}$-moving ice sheets possibly several kilometres thick planed off the tops of the limestone reefs. Beneath the ice sheets, subglacial water led to extensive karstification, forming cave systems, karst corridors, solution dolines, and subglacial channels (Playford et al., 2009). Some of these channels are preserved today as the major gorges cutting through the reefs: most notably Billy Munro Gorge, Windjana Gorge (Figure 7) and Geikie Gorge. Clays of probable Permian age can be seen locally in some gorges and caves.

Permian deposition was thickest and most continuous in the Fitzroy Trough, S of the Lennard Shelf. There, deposition continued sporadically until the Late Permian in siliciclastic-dominated, mixed deltaic to shelfal settings (Mory, 2010).

\section{Mesozoic transgressions}

A veneer of Mesozoic sedimentary rocks up to c. $200 \mathrm{~m}$ thick covers much of the central and southern Canning Basin, thickening to 500- 


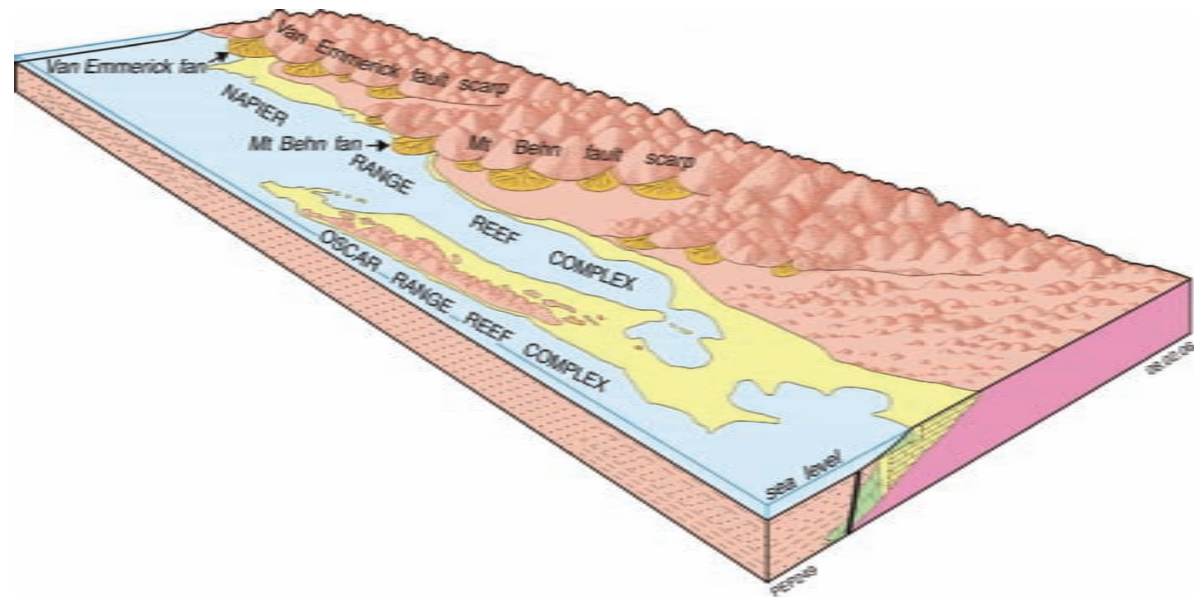

Figure 6 Oblique block diagram (based on actual geography) of Oscar and Napier Range reef complexes and associated conglomerates at Late Frasnian time (from Playford et al., 2009, Figure 180).

$600 \mathrm{~m}$ near the coast. The Triassic succession, characterised by a transgressive marine shale overlain by a prograding deltaic to fluvial succession, is an onshore extension of a much thicker succession in the Roebuck Basin, and is largely restricted to the Fitzroy Trough and outer Lennard Shelf. The Triassic succession is common to the Canning, Roebuck, Northern Carnarvon (where it hosts the giant gas fields of the NW Shelf) and Perth basins, reflecting the onset of Gondwana breakup along Australia's NW margin (Longley et al., 2004).

Along the seaward coast of the Dampier Peninsula, the Lower Cretaceous Broome Sandstone is notable for widespread dinosaur trackways patchily preserved on coastal platforms. The Broome Sandstone marks the start of a post-breakup transgression that extended over much of Australia's interior. In the Canning Basin, deposition was primarily of a fluvial to nearshore, sandstonedominated veneer. West and $\mathrm{S}$ of the Canning Basin (Northern Carnarvon and Gunbarrel basins), and over much of northern South Australia and western New South Wales, the transgression culminated in the Albian with deposition of a radiolarian-rich siltstone.

\section{Evolving landscapes}

The Kimberley region has an ancient landscape that has been evolving following the Neoproterozoic glaciations c. $600 \mathrm{Ma}$, Devonian tectonism in the Alice Springs Orogeny, Permian glaciation c. $280 \mathrm{Ma}$, and tilting of the Australian plate in the Neogene. At least two uplifted planation surfaces are present. The High Kimberley surface formed around 280-200 Ma and is preserved as remnants on the main Kimberley Plateau. Between c. 200-100 Ma, uplift and erosion established the Low Kimberley surface surrounding the main plateau. Either or both surfaces may be related to rifting and Gondwana breakup offshore (Longley et al., 2004) to the $\mathrm{N}$ and then NW.

Australia has drifted $\mathrm{N}$ towards India in the last $24 \mathrm{Myr}$, with the Australian plate bowing beneath the Indian plate. Its southern margin has lifted up, forming the various barrier plains of the Murray River
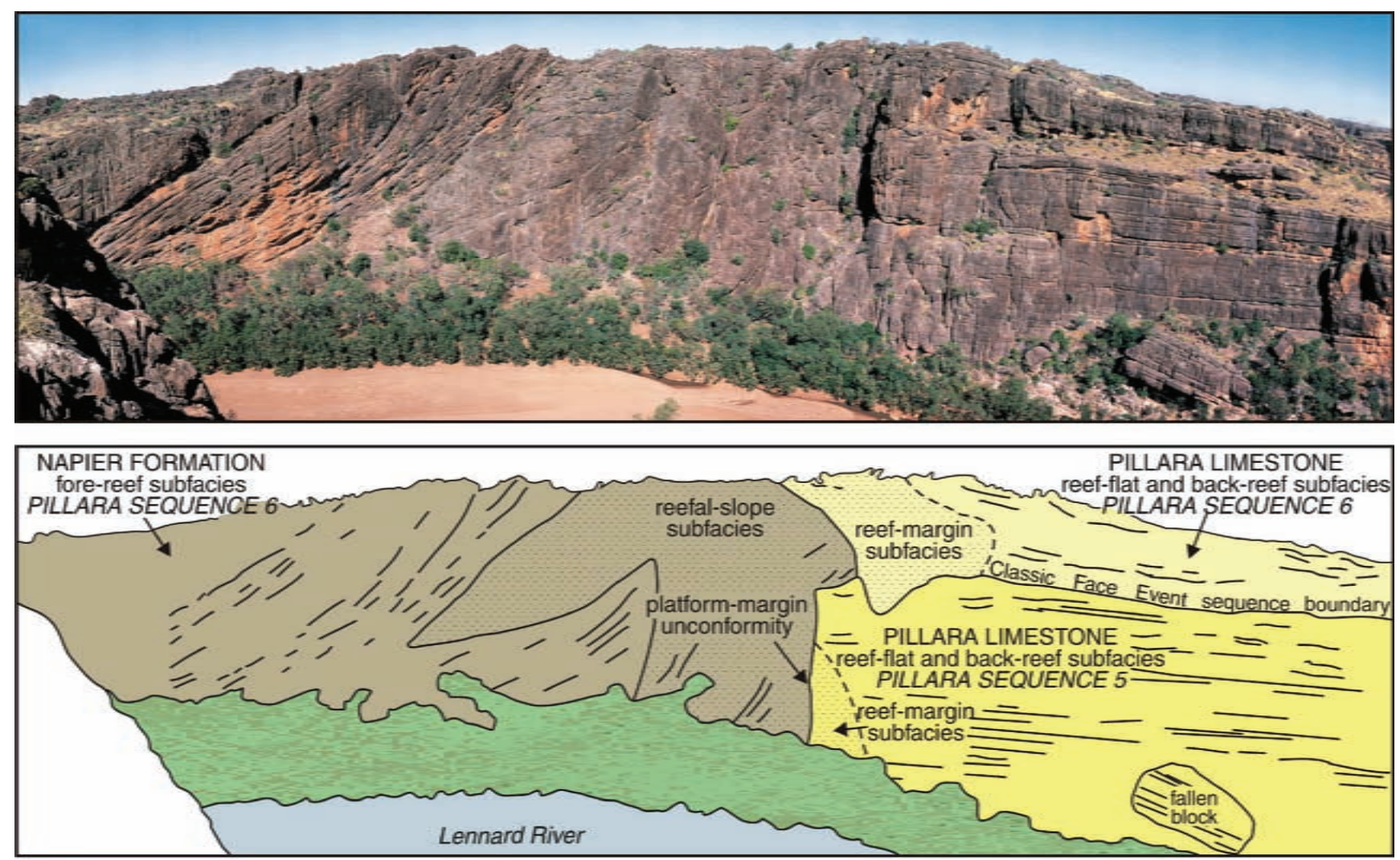

Figure 7 The Classic Face at Windjana looking $S$, showing transition from back-reef deposits at right through reefal facies in centre to fore-reef and marginal slope facies at left (after Playford et al., 2009, Figure 486). 
in South Australia and the elevated Nullarbor Plain of the Eucla Basin, and the northern continental margin has bowed downwards, implying the northern Kimberley coastline may have been progressively drowning since the Miocene, rather than simply during the Quaternary. Drowning has been accentuated by sea level rise after the last ice age c. $17 \mathrm{ka}$.

\section{Mineral deposits and petroleum fields}

The Kimberley region (Figure 1) was the site of Western Australia's first Au rush in 1886 following the discovery of payable $\mathrm{Au}$ in the vicinity of Halls Creek in 1885. The small size of the deposits, the remoteness of the area and the lack of fuel and water meant most of the prospectors left in 1892 on news of new discoveries near Kalgoorlie. In 1951 hematitic Fe ore mines were developed by BHP on Cockatoo and Koolan islands in Yampi Sound, a decade or more before the discovery and development of hematitic Fe ore in the Pilbara region. Exploration for diamonds began in the late 1960's and saw the discovery of two major diamond provinces, Ellendale in the west Kimberley and Argyle in the east Kimberley. The Argyle diamond pipe (AK1), a world class deposit, was discovered in 1979, with mining commencing in 1985 (Jaques et al., 1986).

The area around Halls Creek remains highly prospective for $\mathrm{Au}$ and a number of small-scale alluvial and lode-gold mines have been developed. The Savannah Ni Mine, N of Halls Creek, together with the sub-economic Panton Pt deposit, highlights the considerable potential for the discovery of further mafic-ultramafic intrusion-related mineralisation. Zinc, $\mathrm{Cu}$ and $\mathrm{Pb}$ occurs in volcanic-hosted massive sulfide deposits at Koongie Park, SW of Halls Creek, and Mississippi Valley-type $\mathrm{Zn}-\mathrm{Pb}$ deposits have been mined from the Devonian limestones of the west Kimberley at Pillara and Cadjebut. Bauxite deposits occur on the Mitchell Plateau, and represent deep weathering of underlying basalts in the Kimberley Basin (Smurthwaite, 1990).

A small producing oilfield occurs at Blina in the Canning Basin, and huge reserves of gas are known in the offshore Browse Basin.

\section{Acknowledgements}

This paper is published with the permission of the Executive Director of the Geological Survey of Western Australia. Ian Scrimgeour, Simon Bodorkos and the editors are thanked for their helpful reviews and suggestions.

\section{References}

Bell, T.H. and Mares, V.M., 1999, Correlating deformation and metamorphism around orogenic arcs: American Mineralogist, v. 84; pp. 1727-1740.

Blake, D.H., 1996, How ancient is the Bungle Bungle Range of the East Kimberley, Western Australia? AGSO Research Newsletter, 24, pp. 4-6.

Blake, D.H., Tyler, I.M., Griffin, T.J., Sheppard, S., Thorne, A.M. and Warren, R.G., 1999, Geology of the Halls Creek 1:100 000 Sheet area (4461), Western Australia: Australian Geological Survey Organisation.

Blake, D.H., Tyler, I.M. and Page, R.W., 2000, Regional Geology of the Halls Creek Orogen, in Hoatson, D.M. and Blake, D.H. (eds),Geology and economic potential of the Palaeoproterozoic layered mafic-ultramafic intrusions in the East Kimberley, Western Australia: Australian Geological Survey Organisation, Bulletin 246, pp. 35-62.

Bodorkos, S. and Reddy, S.M., 2004, Proterozoic cooling and exhumation of the northern central Halls Creek Orogen, Western Australia: constraints from a reconnaissance ${ }^{40} \mathrm{Ar} /{ }^{39} \mathrm{Ar}$ study: Australian Journal of Earth Sciences, v. 51, pp. 591-609.

Bodorkos, S., Oliver, N.H.S. and Cawood, P.A., 1999, Thermal evolution of the central Halls Creek Orogen, northern Australia: Australian Journal of Earth Sciences, v. 46, pp. 453-465.

Bodorkos, S., Cawood, P.A., Oliver, N.H.S. and Nemchin, A.A., 2000a, Rapidity of orogenesis in the Paleoproterozoic Halls Creek Orogen, northern Australia: evidence from SHRIMP zircon data, CL zircon images, and mixture modeling studies: American Journal of Science, v. 300, pp. 60-82.

Bodorkos, S., Cawood, P.A. and Oliver, N.H.S., 2000b, Timing and duration of syn-magmatic deformation in the Mabel Downs Tonalite, northern Australia: Journal of Structural Geology, v. 22, pp. 1181-1198.

Cawood, P.A. and Korsch, R.J., 2008, Assembling Australia: Proterozoic building of a continent: Precambrian Research, v. 166, pp. 1-38.

Gellatly, D.C., Derrick, G.M. and Plumb, K.A., 1970, Proterozoic palaeocurrent directions in the Kimberley region, northwestern Australia: Geological Magazine, v. 107, pp. 249-257.

Glass, L.M. and Phillips, D., 2006, The Kalkarindji Continental Flood Basalt Province. A new Cambrian Large Igneous Province in Australia with possible links to mass extinction: Geology, v. 34, pp. 461-464.

Grey, K. and Blake, D.H., 1999, Neoproterozoic (Cryogenian) stromatolites from the Wolfe Basin, east Kimberley, Western Australia: correlation with the Centralian Superbasin: Australian Journal of Earth Sciences, v. 46, pp. 329-341.

Grey, K. and Corkeron, M., 1998, Late Neoproterozoic stromatolites in glacigenic successions in the Kimberley region, Western Australia: evidence for a younger Marinoan glaciation: Precambrian Research, v. 92 , pp. $65-87$.

Griffin, T.J., Tyler, I.M. and Playford, P.E., 1993, Explanatory notes on the Lennard River 1:250 000 geological sheet SE/51-8, Western Australia (3rd edition): Geological Survey of Western Australia, Record 1992/5, $85 \mathrm{pp}$.

Griffin, T.J., Page, R.W., Sheppard, S. and Tyler, I.M., 2000, Tectonic implications of Palaeoproterozoic post-collisional, high-K felsic igneous rocks from the Kimberley region of northwestern Australia: Precambrian Research, v. 101, pp. 1-23.

Haines, P.W., 2009, The Carribuddy Group and Worral Formation, Canning Basin, Western Australia: Stratigraphy, sedimentology, and petroleum potential: Geological Survey of Western Australia, Report 105, 60 pp.

Hancock, S.L., 1991, Tectonic development of the Lower Proterozoic basement in the Kimberley district of northwestern Western Australia: $\mathrm{PhD}$ thesis, University of Adelaide (unpublished).

Hanley, L.M. and Wingate, M.T.D., 2000, SHRIMP zircon age for an Early Cambrian dolerite dyke: an intrusive phase of the Antrim Plateau Volcanics of northern Australia: Australian Journal of Earth Sciences, v. 47, pp. 1029-1040.

Hocking, R.M. and Playford, P.E., 2002, Siliciclastic conglomerates associated with Devonian Reef Complexes, Canning Basin, Western Australia: Geological Society of Australia, Abstracts 67, p. 361.

Hocking, R.M., Playford, P.E., Haines, P.W., and Mory, A.J., 2008, Paleozoic geology of the Canning Basin - a field guide: Geological Survey of Western Australia, Record 2008/18, 39 pp.

Jaques, A.L., Lewis, J.D. and Smith, C.B., 1986, The kimberlite and lamproites of Western Australia: Geological Survey of Western Australia, Bulletin $132,268 \mathrm{pp}$

Longley, I.M., Buessenschuett, C., Clydesdale, L., Cubbitt, C.J., Davis, R.C., Johnson, M.K., Marshall, N.M., Murray, A.P., Somerville, R., Spry, T.B. and Thompson, N.B., 2004, The North West Shelf of Australia - a Woodside perspective, in Keep, M. and Moss, S.J. (eds), The Sedimentary Basins of Western Australia 3, Western Australian Basins Symposium Proceedings , Perth, October 2004: Petroleum Exploration Society of Australia, pp. 29-88.

Mory, A.J., 2010, A review of mid-Carboniferous to Triassic stratigraphy, Canning Basin, Western Australia: Geological Survey of Western Australia, Report 107, 130 pp.

Mory, A.J. and Beere, G.M., 1988, Geology of the onshore Bonaparte and Ord Basins: Geological Survey of Western Australia, Bulletin 134, 184 pp.

Page, R.W. and Hoatson, D.M., 2000, Geochronology of the mafic-ultramafic intrusions in Hoatson, D.M. and Blake, D.H. (eds),Geology and economic potential of the Palaeoproterozoic layered mafic-ultramafic intrusions in the East Kimberley, Western Australia: Australian Geological Survey Organisation, Bulletin 246, pp. 163-172.

Page, R.D., Blake, D.H., Sun, S-S., Tyler, I.M., Griffin, T.J. and Thorne, A.M., 
1994, New geological and geochronological constraints on VMS prospectivity near Halls Creek, W. A.: AGSO Research Newsletter, 20, pp. 5-7.

Page, R.W., Griffin, T.J., Tyler, I.M. and Sheppard, S., 2001, Geochronological constraints on tectonic models for Australian Palaeoproterozoic high-K granites: Journal of the Geological Society of London, v. 158, pp. 535545.

Pidgeon, R.T., Smith, C.B. and Fanning, C.M., 1989, Kimberlite and lamproite emplacement ages in Western Australia in Kimberlites and related rocks, volume 1 , Their composition, occurrence, origin and emplacement: Geological Society of Australia, Special Publication 14, pp. 369381.

Playford, P.E., Hocking, R.M. and Cockbain, A.E., 2009, Devonian reef complexes of the Canning Basin, Western Australia: Geological Survey of Western Australia, Bulletin 145, 444 pp.

Plumb, K.A. and Gemuts, I., 1976, Precambrian geology of the Kimberley region, Western Australia: 25th International Geological Congress, Excursion guide No. 44C, 69 pp.

Shaw, R.D., Tyler, I.M., Griffin, T.J. and Webb, A., 1992, New K-Ar constraints on the onset of subsidence in the Canning Basin, Western Australia: BMR Journal of Geology and Geophysics, v. 13, pp. 31-35.

Sheppard, S., Tyler, I.M., Griffin, T.J. and Taylor, R.W., 1999, Palaeoproterozoic subduction-related and passive margin basalts in the Halls Creek Orogen, northwest Australia: Australian Journal of Earth Sciences, v. 46, pp. 679-690.

Sheppard, S., Griffin, T.J., Tyler, I.M. and Page, R.W., 2001, High- and low$\mathrm{K}$ granites and adakites at a Palaeoproterozoic plate boundary in northwestern Australia: Journal of the Geological Society of London, v. 158, pp. $547-560$.

Smurthwaite, A.J., 1990, Alumina, in Geology and Mineral Resources of Western Australia: Geological Survey of Western Australia, Memoir 3, pp. 615-624.

Sheppard S., Page R.W., Griffin, T.J., Rasmussen, B., Fletcher, I.R., Tyler, I.M., Kirkland, C.L., Wingate, M.T.D. and Thorne, A.M., 2012, The Hart Dolerite of northern Western Australia: a c. 1800 Ma large igneous province: Geological Survey of Western Australia, Record (in press).

Thorne A.M. and Tyler I.M., 1996, Mesoproterozoic and Phanerozoic sedimentary basins in the northern Halls Creek Orogen: constraints on the timing of strike-slip movement on the Halls Creek Fault system: Geological Survey of Western Australia, Annual Review 1995-96, pp. $156-168$

Thorne, A.M., Sheppard, S. and Tyler, I.M., 1999, Lissadell, Western Australia

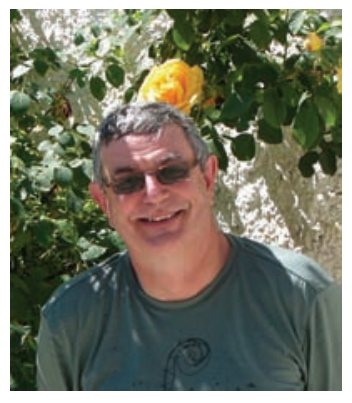

Ian Tyler is Assistant Director for Geoscience Mapping at the Geological Survey of Western Australia. He joined GSWA in 1981 fresh from a PhD in the Scottish Caledonides, specialising in metamorphic petrology and structural geology. His main interest now is in understanding the tectonics of the assembly of Proterozoic Australia, and the associated mineral systems.

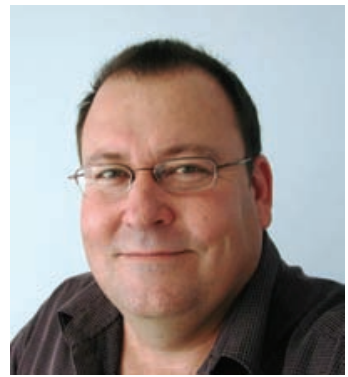

Peter Haines is a senior geologist with the Basins and Energy group at the Geological Survey of Western Australia. He obtained BSc (Hons) (1982) and PhD (1987) degrees from the University of Adelaide, specialising in sedimentology. He has previously worked for the Northern Territory Geological Survey, held research positions at the University of South Australia and University of Adelaide and lectured in Sedimentology at the University of Tasmania. (2nd edition): Geological Survey of Western Australia, 1:250 000 Geological Series Explanatory Notes, 68 pp.

Tyler, I.M., 2000, Geological map of the Halls Creek Orogen, east Kimberley region (1:500 000) in Tyler, I.M., Griffin, T.J., Sheppard, S. and Thorne, A.M. (eds), The geology of the King Leopold and Halls Creek Orogens: Western Australia Geological Survey, Bulletin 143, Plates 3-5.

Tyler, I.M, 2005, Australia - Proterozoic in Selley, R.C., Cocks, L.R.M. and Plimer, I.R. (eds), Encyclopedia of Geology: Elsevier, pp. 208-211.

Tyler, I.M. and Griffin, T.J., 1990, Structural development of the King Leopold Orogen, Kimberley region, Western Australia: Journal of Structural Geology, v. 12, pp. 703-714.

Tyler, I.M. and Griffin, T.J., 1993, Yampi, Western Australia (2nd edition): Geological Survey of Western Australia, 1:250 000 Geological Series, Explanatory Notes, $32 \mathrm{pp}$.

Tyler, I.M. and Hocking, R.M., 2001, Tectonic units of Western Australia (scale 1:2 500 000): Geological Survey of Western Australia, map and data layer.

Tyler, I.M. and Page, R.W., 1996, Palaeoproterozoic deformation, metamorphism and igneous intrusion in the central zone of the Lamboo Complex, Halls Creek Orogen: Geological Society of Australia, Abstracts 41, pp. 450.

Tyler, I.M., Griffin, T.J., Page, R.W. and Shaw, R.D., 1995, Are there terranes within the Lamboo Complex of the Halls Creek Orogen? Geological Survey of Western Australia, Annual Review 1993-94, pp. 37-46.

Tyler, I.M., Griffin, T.J. and Sheppard, S., 1998, Geology of the Dockrell 1:100 000 sheet: Geological Survey of Western Australia, 1:100 000 Geological Series, Explanatory Notes, $31 \mathrm{pp}$.

Tyler, I.M., Page, R.W. and Griffin, T.J., 1999, Depositional age and provenance of the Marboo Formation from SHRIMP U-Pb zircon geochronology: Implications for the early Palaeoproterozoic tectonic evolution of the Kimberley region, Western Australia: Precambrian Research, v. 95 , pp. $225-243$.

Tyler, I.M., Sheppard, S., Bodorkos, S. and Page, R.W., 2005, Tectonic significance of detrital zircon age profiles across Palaeoproterozoic orogens in the Kimberley region of northern Australia: Geological Society of Australia, Abstracts 81, p. 33.

Walter, M.J., Veevers, J.J., Calver, C.R. and Grey, K. 1995, Late Proterozoic stratigraphy of the Centralian Superbasin, Australia: Precambrian Research, v. 73, pp. 173-195.

White, S.H. and Muir, M.D., 1989, Multiple reactivation of coupled orthogonal fault systems: An example from the Kimberley region in northern Western Australia: Geology, v. 17, pp. 618-621.

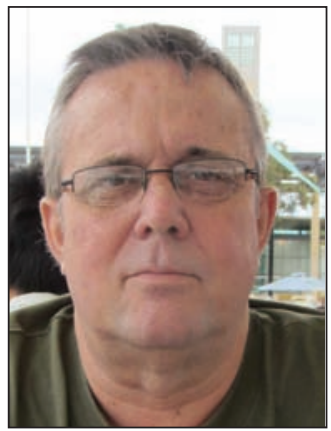

Roger Hocking has worked as a stratigrapher and sedimentologist on siliciclastic and carbonate rocks ranging in age from Archean to Holocene, in undeformed to moderately deformed basins and orogens across Western Australia, with a focus on assembling broad geological frameworks that give context for later workers. Roger has spent his professional career at the Geological Survey of Western Australia, where he is presently Chief Geoscientist. 